\title{
Design of a fuzzy controller for open architecture quadrotor
}

\section{Diseño de un controlador fuzzy para cuadrirrotor en arquitectura abierta}

CHARRE-IBARRA, Saida*†, VALDOVINOS-JIMENEZ, Thonatiu, ALCALA-RODRIGUEZ, Janeth and GUDIÑO-LAU, Jorge

Universidad de Colima, Faculty of Electromechanical Engineering, Carretera Manzanillo-Barra de Navidad Km. 20.5, El Naranjo, 28860, Manzanillo, Colima, Mexico.

ID $1^{\text {st }}$ Author: Saida, Charre-Ibarra / ORC ID: 0000-0002-3823-5388, Researcher ID Thomson: Q-6851-2018, arXiv ID Author: saidacharre

ID $1^{\text {st }}$ Co-author: Thonatiuh, Valdovinos-Jimenez / ORC ID: 0000-0001-6503-1586

ID $2^{\text {nd }}$ Co-author: Janeth, Alcalá-Rodríguez / ORC ID: 0000-0002-0238-3952

ID $3^{\text {rd }}$ Co-author: Jorge, Gudiño-Lau / ORC ID: 0000-0002-0585-908X, Researcher ID Thomson: Q-6844-2018, arXiv ID Author: jorgeglau

\begin{abstract}
The use of quadrotor helicopters has now increased, especially in civilian applications such as maintenance tasks related to power line or large construction status control, surveillance, crop control in agriculture, work processes in the logistics sector, among others. One of the main problems with some of the conventional designs is the lack of stability. This paper presents the design of a controller using an intelligent control technique to achieve the stability of a quadrotor, to experiment an open architecture quadcopter helicopter was developed, the controller was programmed using LabVIEW software and the data acquisition system is based on the NI PCI 6251 card.
\end{abstract}

Fuzzy controller, Quadrotor, Fuzzy rules

\begin{abstract}
Resumen
El uso de helicópteros cuadrirrotores se ha incrementado en la actualidad, especialmente en aplicaciones civiles tales como tareas de mantenimiento relacionadas con el control de estado de líneas eléctricas o grandes construcciones, vigilancia, control de cultivos en la agricultura, en los procesos de trabajo en el sector logístico, entre otros. Uno de los principales problemas que presentan algunos de los diseños convencionales es la falta de estabilidad. En el presente trabajo se presenta el diseño de un controlador utilizando una técnica de control inteligente para lograr la estabilidad de un cuadrirrotor, para experimentar se elaboró un helicóptero cuadrirrotor en arquitectura abierta, el controlador se programó utilizando el software LabVIEW y el sistema de adquisición de datos se basa en la tarjeta NI PCI 6251.
\end{abstract}

Controlador difuso, Cuadrirrotor, Reglas difusasd

Citation: CHARRE-IBARRA, Saida, VALDOVINOS-JIMENEZ, Thonatiu, ALCALA-RODRIGUEZ, Janeth and GUDIÑO-LAU, Jorge. Design of a fuzzy controller for open architecture quadrotor. Journal Computer Technology. 2020. 413:16-25.

\footnotetext{
* Correspondence to Author (Email: scharre@ucol.mx)

$\dagger$ Researcher contributing as first author
} 


\section{Introduction}

Intelligent control techniques that emulate the characteristics of biological systems offer opportunities and advantages to create control systems with new capabilities. The intelligent control is designed to provide a level of intelligence and autonomy in the control decision that allows to improve the performance of a system. It has different tools to emulate the biological behavior that a human being could use to solve a problem; one of them is fuzzy logic or Fuzzy Logic, a branch of AI (Artificial Intelligence) that is capable of handling vague concepts such as "tall" or "young" allowing to build devices that estimate information that is difficult to define. Fuzzy systems have rules determined by the people who directly manipulate the system to be controlled and the mathematical model of the system is not required, unlike conventional control where the system is analytically modeled through a set of equations (Ponce \& Ramírez, 2010) (Wang, 1997).

The modern study of fuzzy logic and partial contradictions has its origins in the 20th century, when Bertrand Russell took up an ancient Greek paradox whose solution could not be found with classical logic.

The concept of fuzzy logic was conceived thanks to the research of engineer Lofty A. Zadeh from the University of Berkeley (California), Lofty introduced the concept around the mid-sixties, at first, I did not name this logic as fuzzy logic if I do not call it the principle of incompatibility. Lofty A. Zadeh described this principle as: "As the complexity of a system increases, our ability to be precise and construct instructions about its behavior decreases to the threshold beyond which precision and meaning are exclusive characteristics" (Guzmán \& Castaño, 2009).

In 1965 Lotfi A. Zadeh published Fuzzy Sets. This article describes the mathematics of fuzzy sets and by extension of fuzzy logic, this work gave the field its name. Applying Lukasiewiez's logic he created a complete algebra for fuzzy sets (Zadeh, 1965).
Fuzzy logic was applied in the mid-1970s by Ebrahim H. Mamdani at Queen Mary College in London. Mamdani designed a fuzzy controller for a steam engine. Since then, the term fuzzy logic is synonymous with any mathematical or computational system that reasons with fuzzy logic (Castillo, 2015).

At present, fuzzy logic is quite common and has great industrial application in different areas related to technology, such as electronics, control and robotics, among others. For example, in the automotive industry it has also been taken advantage of, Nissan has had an antilock braking system since 1997 that detects wheel speed, conditions and driving pattern, and diffuse ABS determines the braking action, with slip control (Von, 1994).

Since 1988, Hitachi has delivered the control of the Sendai metro to a diffuse system and has reduced errors in acceleration and braking by 70\% (Ponce \& Ramírez, 2010).

Applications in simpler systems have also been demonstrated, such as an environment regulator that is used to release hot air when the temperature is low and close it when the temperature is very high (Castaño, 2009).

A quadrotor helicopter or more commonly known as a drone, is an unmanned aerial vehicle that has four rotors, generally placed at the extremities of a cross. Control of vehicle movement is achieved by varying the relative speed of each rotor to change the thrust and torque produced by each of them (figure 1).

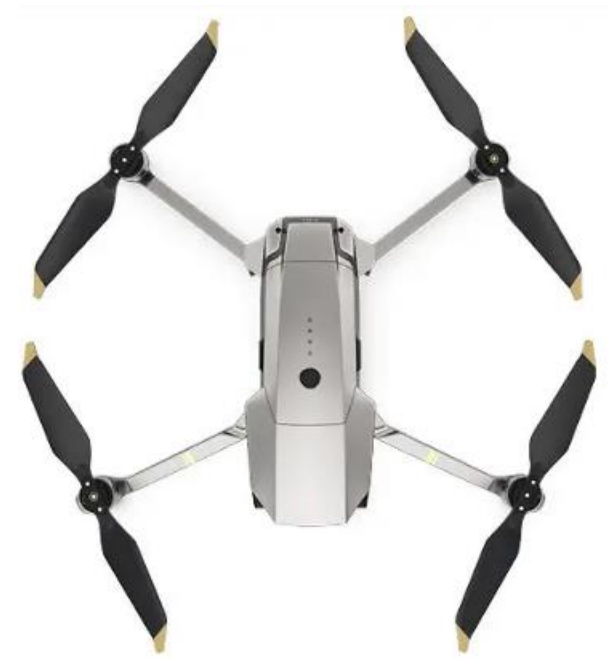

Figure 1 Dron cuadrirrotor Mavic Pro Platinum Source: (DirectINDUSTRY) 
The use of drones is increasingly common within society, and the subject of drones continues to be investigated in different areas, such as the case of research aimed at the implementation of neural algorithms for stabilizing the flight of a drone carried out by students of the National Polytechnic Institute (Medina, 2017), the development of works to control the height of the AR.Drone 2.0 quadrotor using fuzzy logic (Campos etal, 2019), the design and construction of an unmanned aerial vehicle type quadcopter applying the law control based on sliding modes (Lara et al., 2017), and the application of diffuse systems applied to unmanned aerial vehicles for the monitoring of green areas (Balanza et al., 2016).

In this work, the design of an intelligent controller based on fuzzy logic for a Quadcopter built in open architecture is presented, it begins with the presentation of the prototype and later the design and programming of the fuzzy controller is carried out in LabVIEW software, presenting in an interface graphical trajectories followed by the prototype to achieve stabilization.

\section{Design and implementation of the quadcopter in open architecture}

A test bench was built to place the prototype and be able to experiment with it safely. The test bench had to withstand the loads and vibrations of the quadrotor.

Before manufacturing, it was designed in a CAD program (Computer Aided Design), the final result was the design shown in Figure 2, with dimensions at the base of $30 \mathrm{~cm}$ long by 2.5 $\mathrm{cm}$ wide, for the Side supports, pieces of the same material were used with measures of $20 \mathrm{~cm}$ high with the same width and a separation between each support of $15 \mathrm{~cm} .1 / 4$ inch PTR was used for its physical construction.

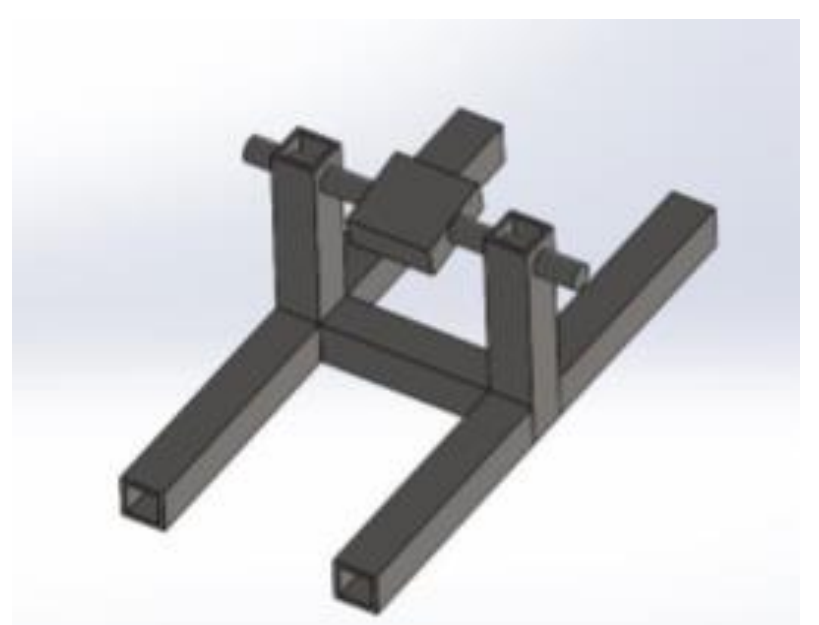

Figure 2 Testing bench Source: Self-made

Figure 3 shows the result of the physical construction of the bench to place the quadrotor, in the lateral supports of the structure holes were made for the placement of a transverse axis, with the function of providing movement, in the same way I implement a wooden base with 4 holes for fastening with 2-inch screws.

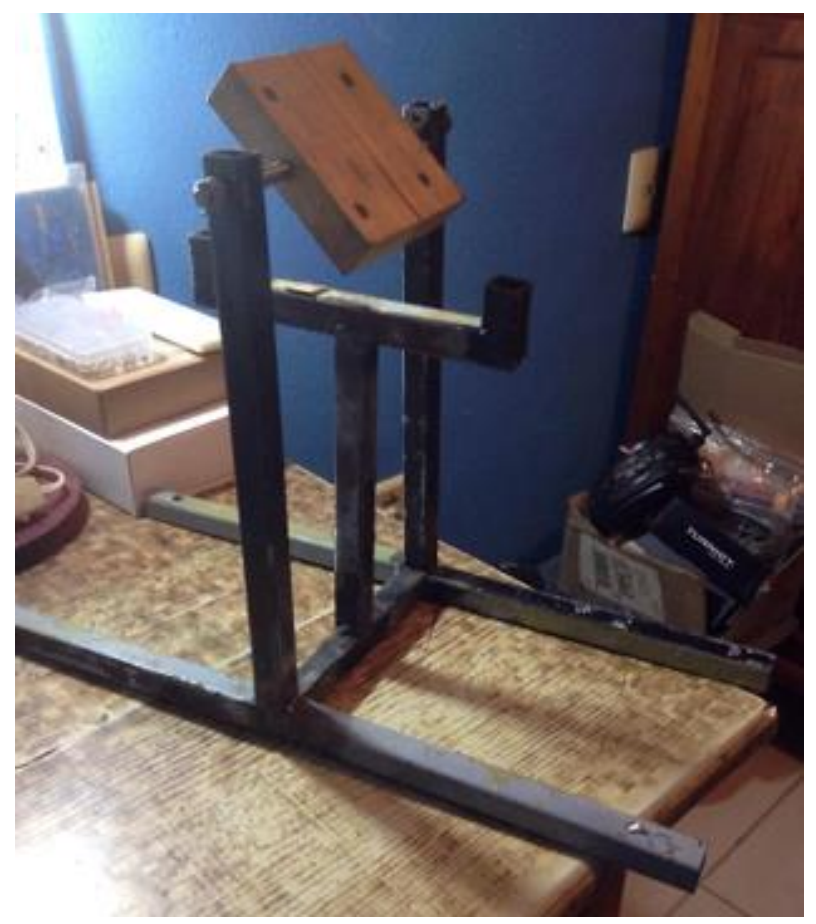

Figure 3 Testing bench

Source: Self-made

For the base of the quadrotor where the circuits are mounted as well as the motors with their respective propellers, a frame designed with rigid plastic material was used for a quadrotor of the DJI brand model 4450 resistant to shocks and vibrations, with mounting dimensions in the engines suitable for those required (Figure 4). 


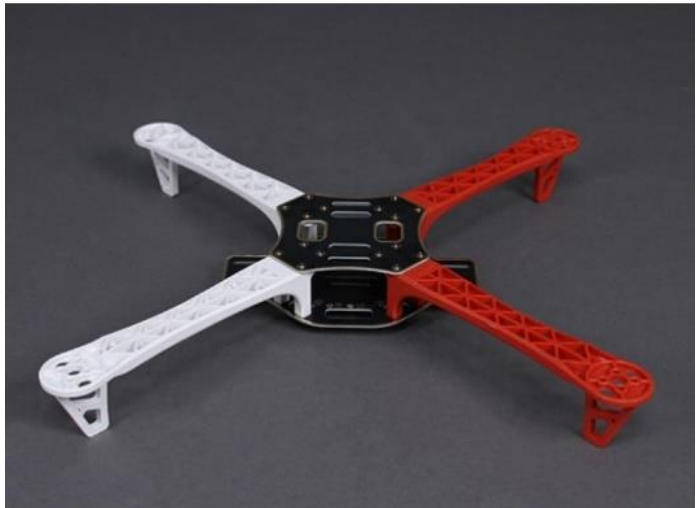

Figure 4 Quadcopter frame f450 Source: (DJI)

Using the SolidWorks software, the scale model of the structure was made with the measurements corresponding to those of the physical frame (Figure 5), in the center of the structure there are two clamping plates, the lower plate is made copper coated with nonconductive paint, this is responsible for the connection with the battery and also the connection of the motors for its power supply, the upper plate is the base where the controller plate is located, providing accessibility to the circuits for adjusting values or settings in the program.

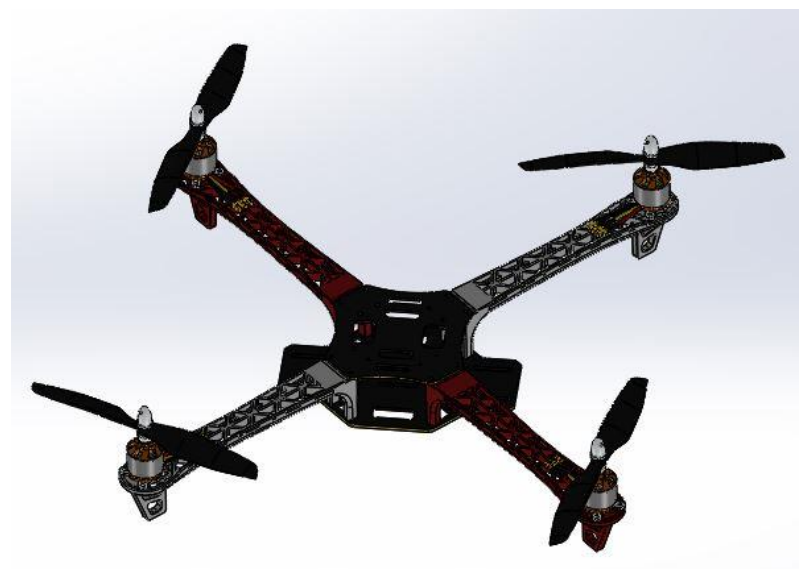

Figure 5 Scale Modeling of the Quadcopter Helicopter in SolidWorks

Source: Self-made

Figure 6 shows the quadcopter mounted on the test bench, as well as some of its components.

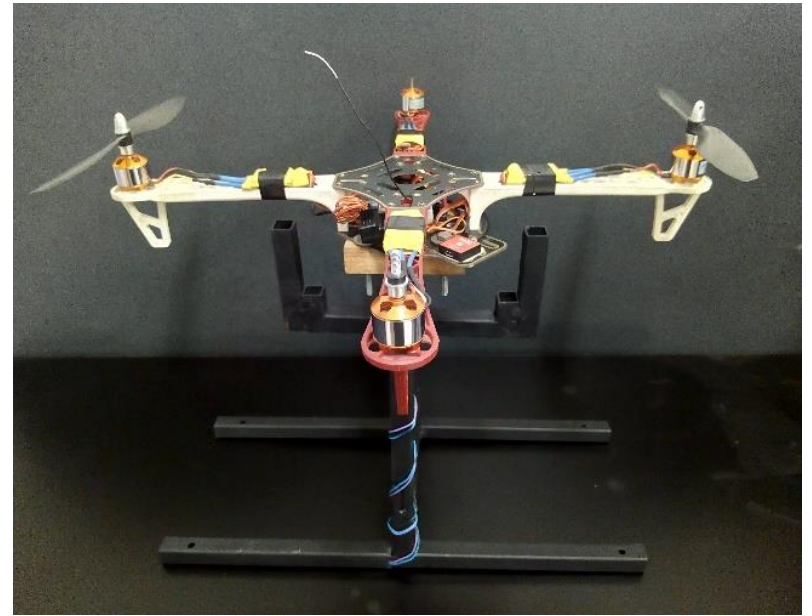

Figure 6 Quadrotor mounted on test bench Source: Self-made

The main parts and devices that make up the prototype designed and developed entirely by the authors of the project are described below:

Brushless Motor A2212 / 13T 1000KV. Brushless or brushless motor controlled by PWM. Ideal for Quadcopter type flight systems. They are also used in fixed wing aerial vehicles. The motor supports up to $12 \mathrm{~A}$ and it is recommended to use a 30A ESC controller, Figure 7.

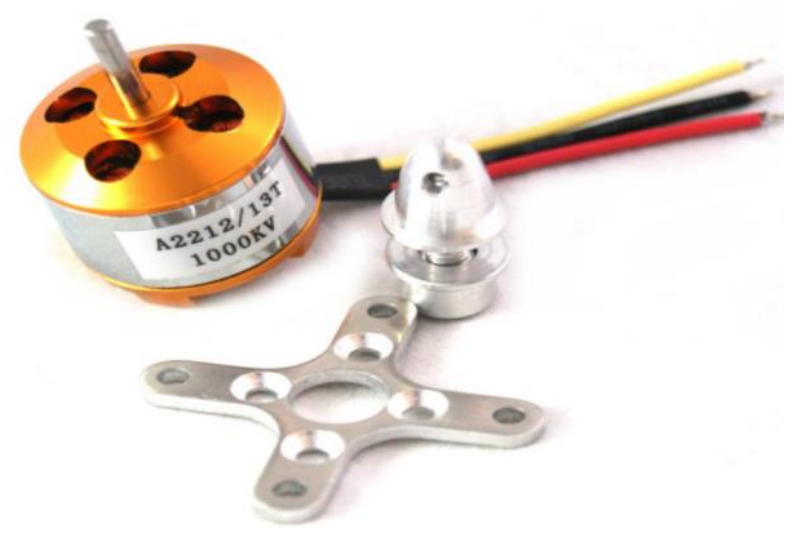

Figure 7 Brushless motor Source: (HETPRO)

This motor shows much higher performance than a brushed DC motor. When calculating the thrust with respect to the weight of the device, it was concluded that the kilovolts (kv) factor of these motors is sufficient to be able to lift. The "kv" factor in a brushless motor, normally appears next to the number of turns of the motor's winding, and what it indicates is the number of revolutions per minute at which it can turn for each volt of electricity applied to it. 
Considering that the weight of the device is $1.2 \mathrm{~kg}$ with a consumption of $9.3 \mathrm{~A}$, the force of a motor is $620 \mathrm{gr}$ which is $6.076 \mathrm{~N}$, there are 4 motors, so with a current of $37.2 \mathrm{~A}$ we have a vertical force of $24,304 \mathrm{~N}$.

According to Newton's second law

$F=m a$

(1)

\section{Where $\mathrm{F}$ is Force \\ $\mathrm{m}$ is mass. \\ $\mathrm{a}$ is acceleration.}

Using (1) and taking into account that the mass is $1.2 \mathrm{~kg}$, and the force is $24.304 \mathrm{~N}$, the acceleration would be:

$a=\frac{24.304 \mathrm{~N}}{1.2 \mathrm{~kg}}=20.25 \mathrm{~m} / \mathrm{s}^{2}$

And subtracting the acceleration from gravity:

$a=20.25 \frac{m}{s^{2}}-9.81 \frac{m}{s^{2}}=10.44 \frac{m}{s^{2}}$

So it is feasible to use the selected engines.

ESC (Electronic Speed Controller). Electronic device used to control the speed of the brushless motor through a Pulse Width Modulation (PWM) signal of $50 \mathrm{~Hz}$ and depending on the length of the pulse width, it will deliver more or less power to the motor (Figure 8).

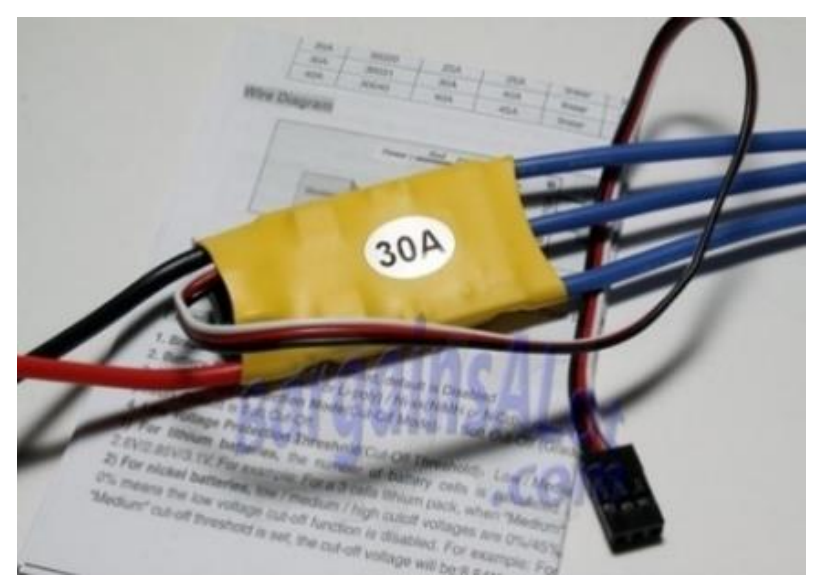

Figure 8 Electronic Speed Controller Source: (HETPRO)
Propellers They are implanted in the motors and are of the utmost importance since they oversee making the rotation of the motors produce a vertical force that pushes the air and can make the quadrotor take off from the ground and keep it there until the power of the motors is decreased by the user in control (Figure 9).

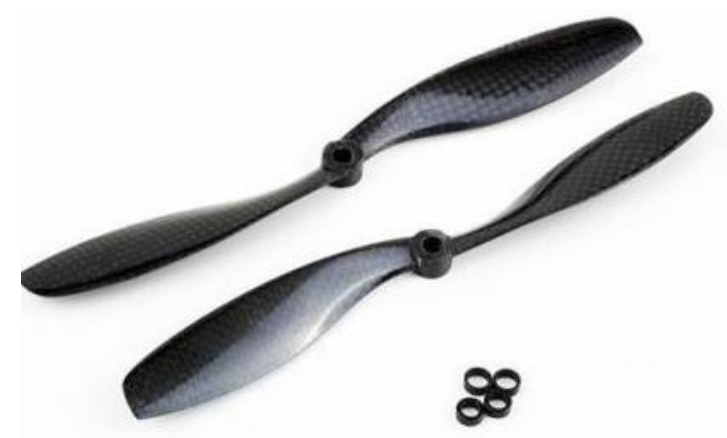

Figure 9 Propellers

Source: (HETPRO)

Li-Po battery. It is a type of rechargeable battery that is usually used in electronic radio control systems mainly in airplanes, helicopters and quadrotors, these batteries are usually small and light thus avoiding being a burden for the drone, since exceeding the weight they support can cause wear or failure of the engines (Figure 10).

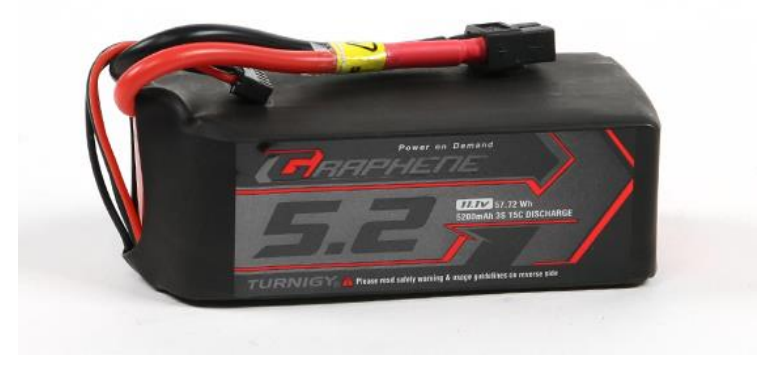

Figure 10 Bateria Li-Po Fuente: (DJI)

Data acquisition card (DAQ). The main component of the data acquisition system is the DAQ measurement hardware, which allows a computer to communicate with a physical process and interact with it, performing control tasks, recording signals, among others. The NI PCI-6251 card, M Series high-speed multifunction card, is used in this system (Figure 11). 


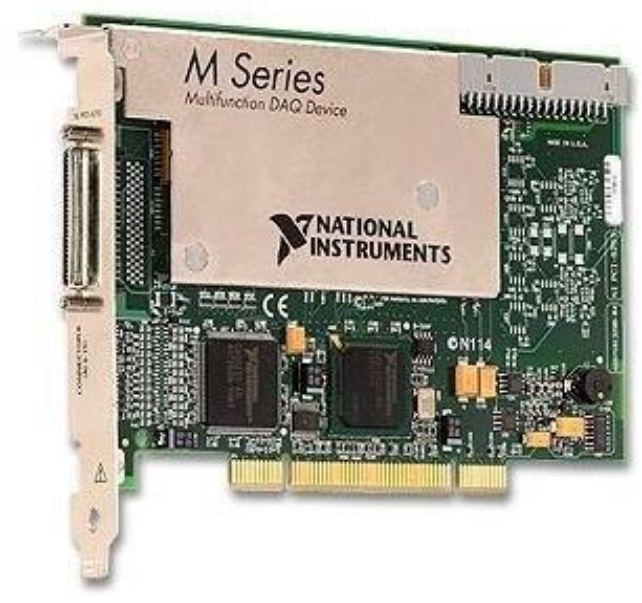

Figure 11 NI PCI 6251 card

Source: (National Instruments)

To carry out a safe handling of signals in the quadrotor, a circuit was designed to isolate the PWM that is sent to the prototype, in this way, the PCI card used in the data acquisition system is protected.

The circuit that was designed for the PWM signals uses optocouplers for the separation of the PCI card with respect to the speed regulators of the brushless motors, in Figure 12 the circuit diagram is presented.

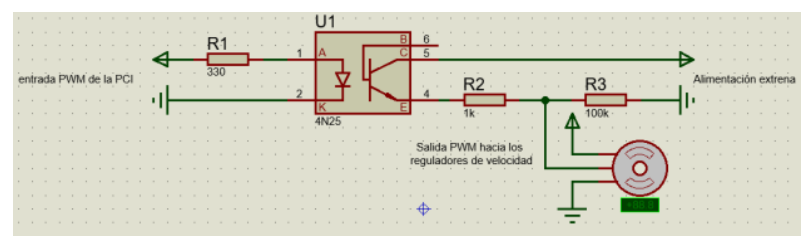

Figure 12 Protection circuit diagram Source: Self-made

Figure 13 shows the electronic protection circuit developed.

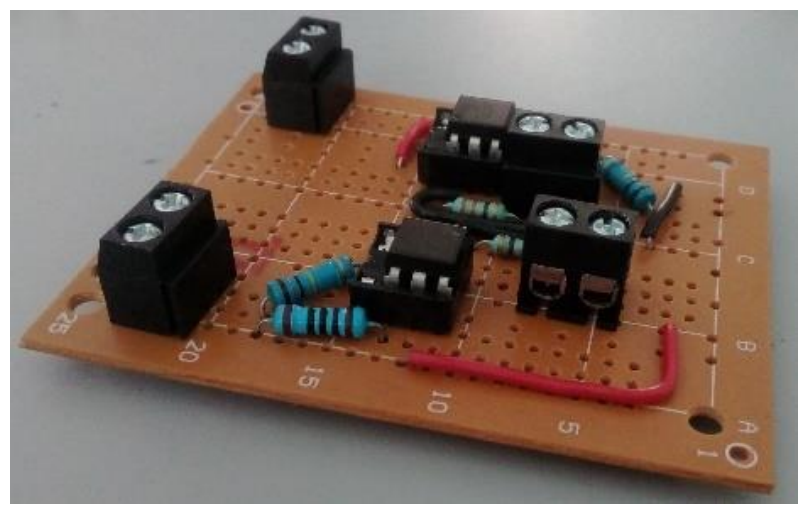

Figure 13 Protection circuit Source: Self-made
On the other hand, a box was designed that would allow the battery that powers the quadcopter to remain fixed in the prototype and could be disconnected when recharging was necessary. The Solidworks program was used, which made it possible to design a plate that could be assembled to the quadrotor structure in a precise way.Once the plate model had been made, the 3D printing was continued, as shown in Figure 14.
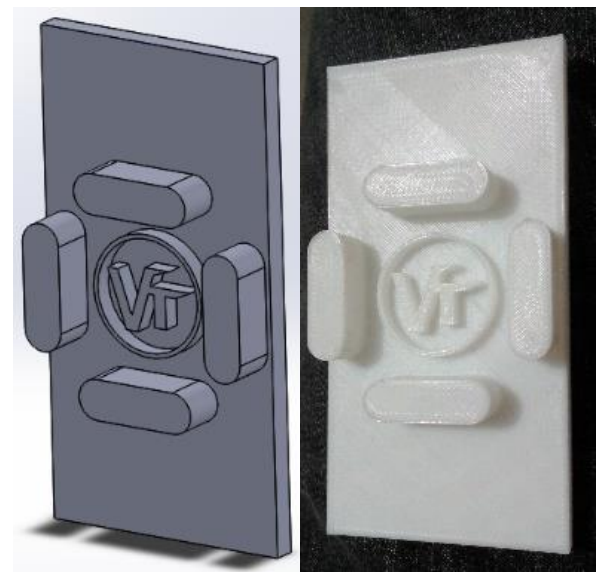

Figure 14 Battery base

Source: Self-made

In Figure 15 you can see the equipment developed to experiment control techniques focused on handling quadrotors.

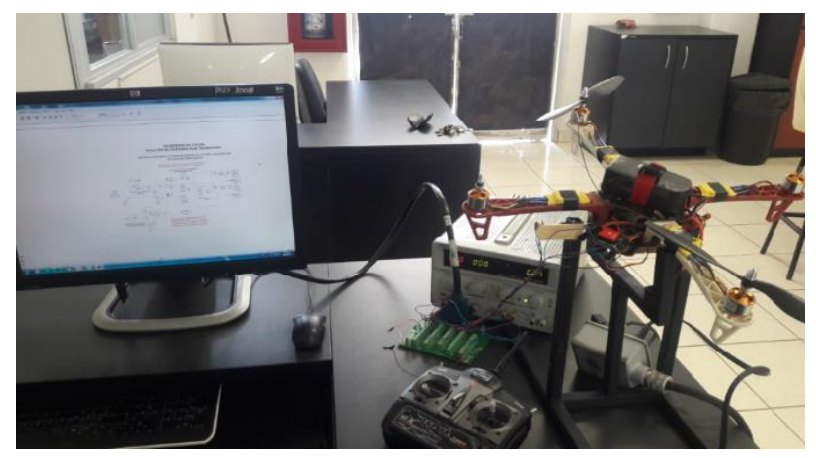

Figure 15 Experimental equipment Source: Self-made

\section{Fuzzy controller design}

Figure 16 shows a block diagram of the control system, the reference value is the desired tilt value $\left(0{ }^{\circ}\right.$ value to keep the drone in a stable position), the fuzzy controller adjusts the rotational speed of the motors by means of the PWM signal so that these take the quadrotor to the desired position. 
Within the process, the quadrotor may be subject to disturbances, which are reflected in its inclination. The drone's position generates a voltage variation through a potentiometer and the process is repeated until the desired position is reached (Figure 16).

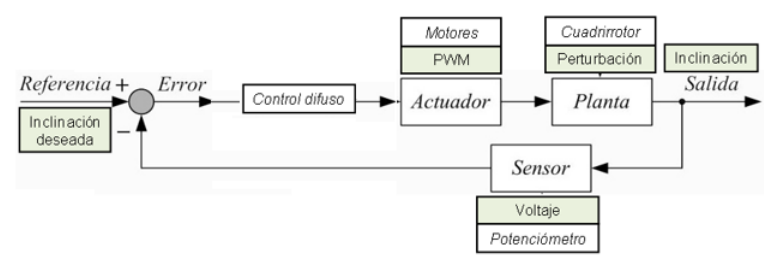

Figure 16 Closed loop control system diagram Source: Self-made

Figure 17 shows the devices and equipment that make up the control loop and the connection between them, it is observed how the PWM signal generated by the fuzzy controller programmed in the computer is sent from the NI PCI 6251 acquisition card to the regulators speed, which are responsible for controlling the speed of the motors, responsible for modifying the position of the quadcopter. The drone inclination is read by the acquisition card through the voltage variation that is created in the potentiometer placed on the axis of the quadcopter base.

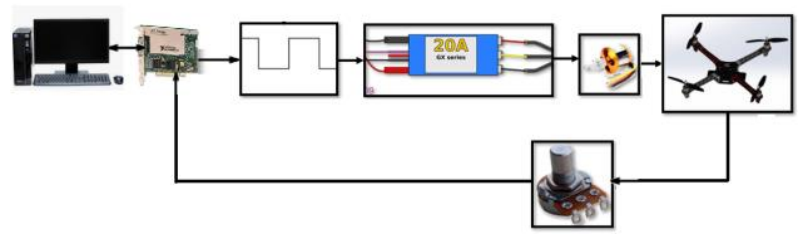

Figure 17 Components in the closed loop control system Source: Self-made

The graphical interface and the programming of the controller was carried out in the LabVIEW graphical programming software, Figure 18 shows the block diagram of the program for reading the potentiometer that provides the inclination present in the drone.

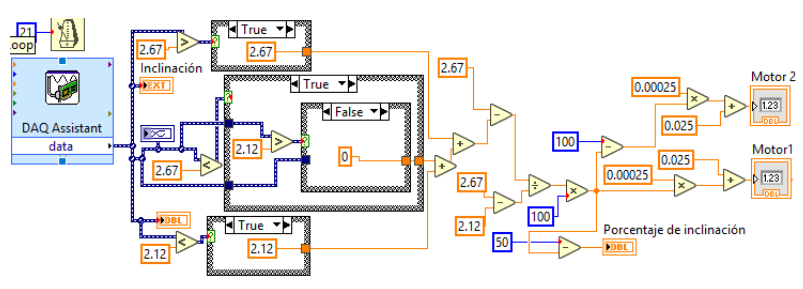

Figure 18 Program for reading the position of the drone Source: Self-made

The variables involved in the fuzzy controller are the following:
- Inclination (given as a percentage, 100\% corresponds to the incline fully to the right and $0 \%$ to the incline completely to the left).

- $\quad$ Input velocity (given in a range from -3.5 to 3.5 , the sign el determines the direction of the velocity).

Output speed (given in percentage, for later conversion to a duty cycle value).

They are listed in table 1 with the corresponding labels.

\begin{tabular}{|l|l|l|l|l|l|}
\multicolumn{2}{|c|}{$\begin{array}{l}\text { Angular tilt } \\
\text { percentage) }\end{array}$} & $\begin{array}{l}\text { Relative } \\
\text { angular } \\
\text { velocity }\end{array}$ \\
\hline FI & Left End & MI & $\begin{array}{l}\text { Very } \\
\text { Fast } \\
\text { Left }\end{array}$ & IV & $\begin{array}{l}\text { Minimum } \\
\text { speed }\end{array}$ \\
\hline SI & $\begin{array}{l}\text { Semifinal } \\
\text { Left }\end{array}$ & RI & $\begin{array}{l}\text { Fast } \\
\text { Left }\end{array}$ & DL & Too slow \\
\hline LI & Left side & PI & $\begin{array}{l}\text { Little } \\
\text { Fast } \\
\text { Left }\end{array}$ & ML & Very slow \\
\hline PI & Little Left & SV & $\begin{array}{l}\text { No } \\
\text { speed }\end{array}$ & LL & Slow \\
\hline MI & $\begin{array}{l}\text { Minimum } \\
\text { Left }\end{array}$ & PD & $\begin{array}{l}\text { Very } \\
\text { Fast } \\
\text { Right }\end{array}$ & PL & Little slow \\
\hline CP & $\begin{array}{l}\text { Center } \\
\text { position }\end{array}$ & RD & $\begin{array}{l}\text { Quick } \\
\text { Right }\end{array}$ & NL & $\begin{array}{l}\text { Nothing } \\
\text { slow }\end{array}$ \\
\hline MD & $\begin{array}{l}\text { Minimum } \\
\text { Right }\end{array}$ & MD & $\begin{array}{l}\text { Little } \\
\text { Quick } \\
\text { Right }\end{array}$ & ME & $\begin{array}{l}\text { Less than } \\
\text { Normal }\end{array}$ \\
\hline PD & $\begin{array}{l}\text { Little } \\
\text { Right }\end{array}$ & & & VM & $\begin{array}{l}\text { Average } \\
\text { speed }\end{array}$ \\
\hline LD & Right side & & $\begin{array}{l}\text { MA } \\
\text { Sore than } \\
\text { Normal }\end{array}$ \\
\hline SD & $\begin{array}{l}\text { Semifinal } \\
\text { Right }\end{array}$ & Right End & & NR & $\begin{array}{l}\text { Nothing } \\
\text { fast }\end{array}$ \\
\hline FD & & PR & Little fast \\
\hline Quick \\
\hline
\end{tabular}

Table 1 Variable labels Source: Self-made

Table 2 presents the rules programmed in the fuzzy controller to achieve stabilization of the drone. 


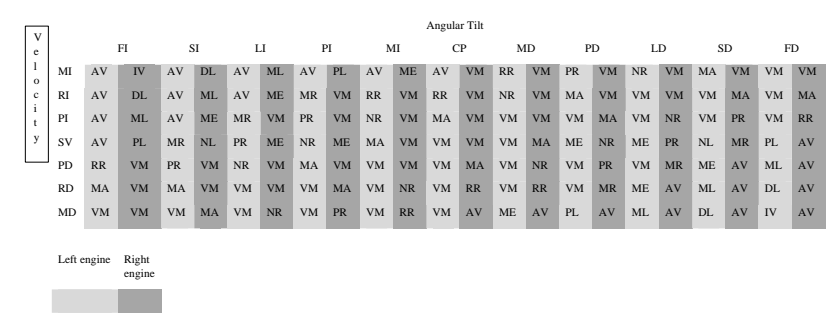

Table 2 Fuzzy controller rules Source: Self-made

The fuzzy controller was programmed using the Labview "Fuzzy System Designer" library. Figure 19 shows the membership functions of each of the variables used.

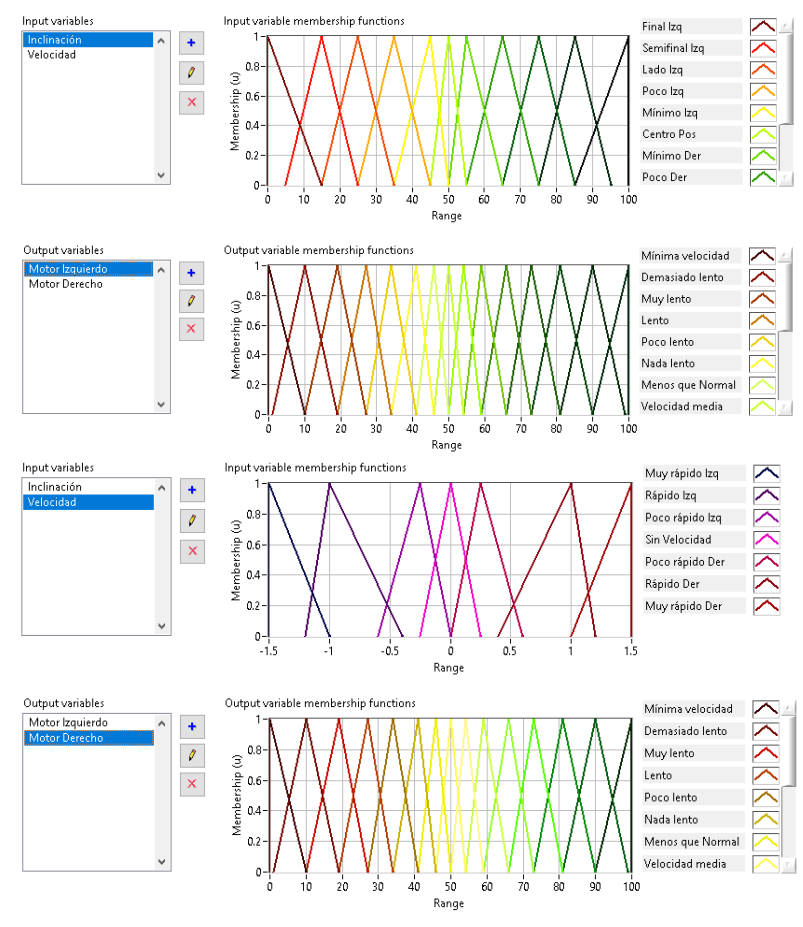

Figure 19 Membership features

Source: Self-made

To observe the transient response of the drone, an interface was designed, where some parameters necessary to interact with the prototype can be established, Figure 20.

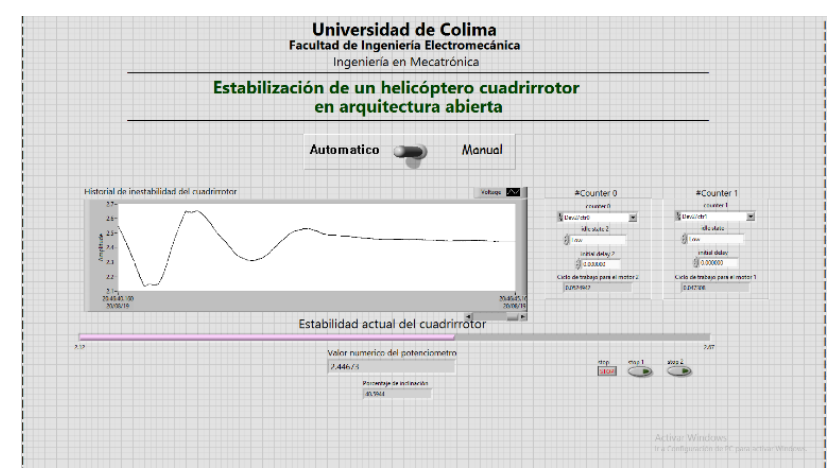

Figure 20 Graphic interface

Source: Self-made

\section{Results}

Different tests were carried out to observe the stabilization in the central position of the drone after experiencing a significant disturbance caused by a sudden change in the inclination and speed in it, Figure 21.

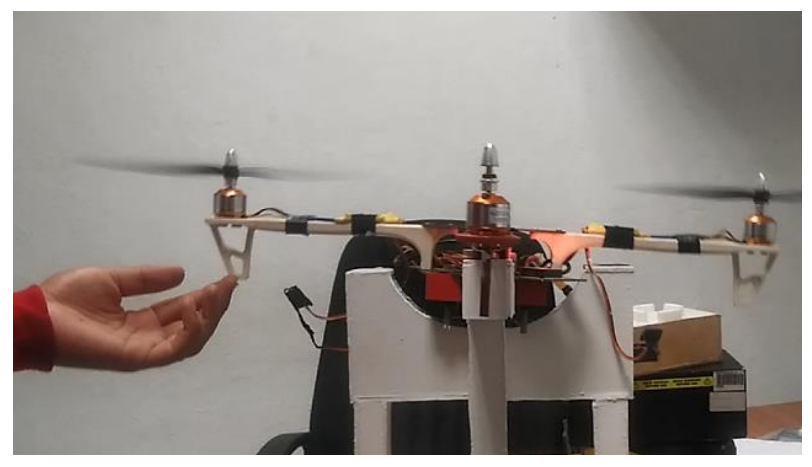

Figure 21 Drone subjected to a disturbance Source: Self-made

The results of the tests are presented in Figure 22. The approximate time for the quadrotor to stabilize (0-degree tilt) after a disturbance is 7 seconds.

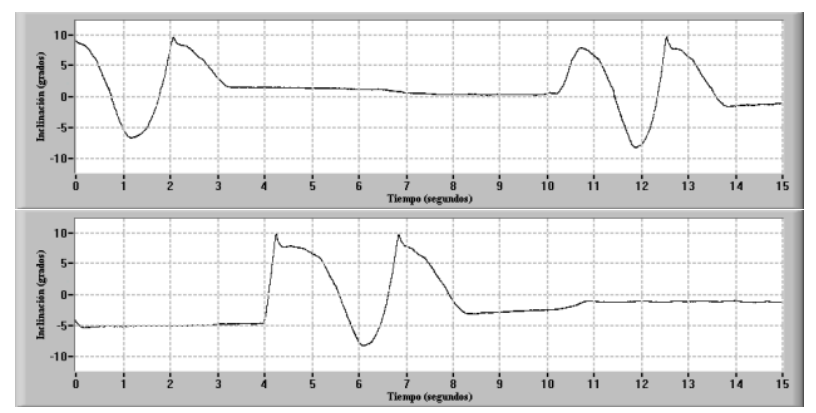

Figure 22 Graphs of the stabilization behavior of the quadrotor subjected to disturbances

Source: Self-made

Another test carried out was to bring the drone to the corresponding position of zero degrees starting from a state of rest. In this test, the drone was located on each side of the test bench structure, in Figure 23 it started from an initial position of -10 degrees and in Figure 24 from 10 degrees, in both cases it managed to be located at zero degrees in approximately 4 seconds.

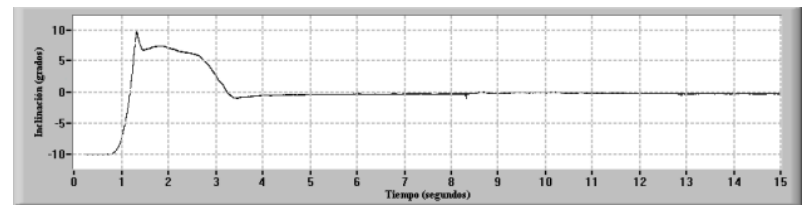

Figure 23 Quadcopter stabilization graph starting from a -10-degree tilt Source: Self-made

CHARRE-IBARRA, Saida, VALDOVINOS-JIMENEZ, Thonatiu, ALCALA-RODRIGUEZ, Janeth and GUDIÑO-LAU, Jorge. Design of a fuzzy controller for open architecture quadrotor. Journal Computer Technology. 2020 


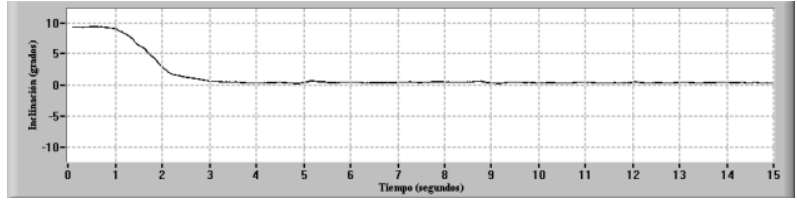

Figure 24 Quadrotor stabilization graph starting from a 10-degree tilt

Source: Self-made

\section{Conclusions}

With the development of this work, the usefulness of the implementation of a fuzzy system for the control of multirotor helicopters was demonstrated, the fuzzy control design does not require the mathematical model of the process, since it bases its operation on the knowledge of an expert, obtained with experience, and incorporates the common language to the design of the control system, adapting better to the real world as it works and understands our own expressions. For the controller design it was necessary to experiment with the drone through an interface, where the effects of the voltage variations received by the brushless motors could be observed.

The transfer to the control system of the specialized information regarding the form of control of the variables occurs in the construction of the rules, a very important and delicate stage, where several alternatives were considered, observing that with the greatest number of rules and functions of membership achieved a shorter stabilization time and a smoother transient response.

The importance of stabilizing drones today is extremely important, as they are currently used in many important tasks, such as sending packages and information through preprogrammed drones, the analysis of optimal terrain for construction through aerial captures, search and rescue tasks. Therefore, it is important to ensure stability during your flight, as there are many factors or disturbances that can intervene in it.

The stabilization objective of a drone was achieved with an intelligent control technique, applying tests with disturbances; as well as the quadrotor was able to return to a stable position and stay there from any initial position.
The prototype of the quadrotor built in open architecture will allow to continue experimenting with different control techniques for the development of future research works.

\section{Acknowledgments}

To the Faculty of Electromechanical Engineering of the Universidad de Colima.

\section{References}

Balanzá, J., Velasco, G., Kémper, N. (2016). Sistema difuso aplicado a lanzaderas de $\mu$-UAVs de ala fija en el monitoreo de zonas verdes (tesis). Universidad Nacional Autónoma de México.

Campos, F., Pinzón. V., Robayo, F. (2019). Fuzzy control of quadrotor Ar. Drone 2.0 in controlled environment, Visión Electrónica, Vol. 13 no. 1, p.p. 39-49, issn 1909-9746, Bogotá. Colombia.

Castaño (2009). La Lógica difusa en ingeniería: Principios, aplicaciones y futuro, Ciencia y Tecnología, 24(2): 87-107, ISSN: 0378-0524.

Castillo (2015), Historia de la lógica difusa. Recovered December 14, 2020: https://sites.google.com/site/logicadifusaingind ustrialpaita/logica-difusa/historia-de-la-logicadifusa

Castillo, P., García, P., Lozano, R., Albertos, P. (2015) Modelado y estabilización de un helicóptero con cuatro rotores. Revista Iberoamericana de Automática e Informática industrial (RIAI).

DirectINDUSTRY, Dron cuadrirrotor Mavic Pro Platinum. R Recovered December 14, 2020: https://www.directindustry.es/prod/djiinnovations-company-limited/product-1016591980430.html

DJI, Bateria Li-Po. Recovered December 17, 2020: Gens Ace 5200mAh 11.1V 10/20C 3S2P Bateria Lipo (multicoptero.com)

DJI, Marco para cuadrirrotor f450. Recovered December 15, 2020: https://www.dji.com $/ m x /$ search $? q=f 450$ 
Guzmán, D., Castaño, V. (2009). La lógica difusa en ingeniería: principios, aplicaciones y futuro, Universidad Nacional Autónoma de México.

HETPRO, Motor brushless, controlador ESC y hélices. Recovered December 15, 2020: Kit Motor Brushless, controlador ESC y helices | HeTPro (hetpro-store.com)

Lara, M., Fagua, Y., Salamanca, M., Higuera, O. (2017). Diseño e implementación de un sistema de control de vuelo para un vehículo aéreo no tripulado tipo cuadricóptero. Tecnura, Vol. 21, No. 53, pp. 32-46, e-ISSN: 2248-7638.

Medina, S. (2017). Implementación de algoritmos neuronales para estabilización de vuelo de un dron (tesis), Instituto Politécnico Nacional, México.

National Instrumens, NI PCI 6251. Recovered December 17, 2020: ni.com/manuals.

Ponce, P., Ramírez, F. (2010). Intelligent Control Systems with LabVIEW, Springer.

Von, C. (1994). Fuzzy logic technologies in automotive engineering. IEEE Proceedings of WESCON, Anaheim, CA, 27-29.

Wang, L. (1997). A course in fuzzy systems and control, Prentice-Hall International.

Zadeh, L.(1965). Fuzzy sets, Inf. Control, vol. 8, pp. 338-353. 